\title{
STUDY ON AFLATOXINS IN SOME FOODSTUFFS WITH SPECIAL REFERENCE TO PUBLIC HEALTH HAZARD IN EGYPT
}

\author{
A. H. EL-GOHARY ${ }^{1}$ \\ Dept of Animal Hygiene and Zoonoses, Faculty of Veterinary Medicine, Alexandria University, Egypt
}

\section{Summary}

A total of 455 food samples representing 22 different food types were collected from several localities at Alexandria province in Egypt. Aflatoxin B1 and aflatoxin M1 were detected in 5 out of $455(1.1 \%)$ of these food samples. From the same samples 206 fungal isolates were obtained. Thirty two of these isolates (15.5\%) were found to be aflatoxin producers. Aspergillus flavus was the dominant isolate, while Aspergillus parasaticus was also isolated from a few other food samples. Among locally consumed foodstuffs. Peanut (7.5\%) and Milk powder (6.6\%) were found to be a suitable substrates for aflatoxin production. The hygienic and public health significance of the isolated aflatoxigenic strains were discussed.

(Key Words : Aflatoxin, Aspergillus flavus, Aspergillus parasaticus, Foodstuffs)

\section{Introduction}

Aflatoxins, a group of toxic metabolites produced by certain Aspergillus species, have been found to be carcinogenic, teratogenic and mutagenic to several species of experimental animals (Butler and Barnes, 1968; Gopalan, et al., 1972 and Adamson, et al., 1973). A total of four metabolities have been designated according to their flourescent colours and chromatographic positions into aflatoxin B1, B2, G1 and G2.

Aflatoxins occur in a variety of crops and animal products such as meat, milk and eggs. The production of aflatoxins is affected by several factors which influence the mould growth such as moisture contents, relative humidity (RH), temperature, substrate composition and the presence of competing microorganisms (Ciegler, 1977). The common occurrence of aflatoxins in foodstuffs and their possible role in the incidence of liver cancer cause world wide concern and research in many countries.

The aim of this study was to investigate, detect and evaluate the presence of aflatoxins and aflatoxigenic fungi in some Egyptian foodstuffs marketed at Alexandria Province with special reference to its public health hazards, in Egypt country.

\footnotetext{
${ }^{1}$ Address reprint requests to Dr. A. H. EL-GOHARY, Dept. of Animal Hygiene and Zoonoses, Faculty of Veterinary Medicine, Alexandria University, Egypt

Received October 27, 1994.

Accepted May 1, 1995
}

\section{Materials and Methods}

A total of 455 food samples were collected from different localities at Alexandria Province in Egypt. The samples included wheat (Triticum aestivum), barley (Hordeum sativum), corn (zea mays), crushed wheat (burghol), peanut, rice, broad beans (Vicia faba), hazelnuts, chickpeas (chicken feed), sesame seeds (sesame paste), milk powder, cowpeas, peas, vetch, dried figs, pine nut, liquorice (urk-us-sus), ferngreek seeds (trigonella faenum-graecum), spices, lentil and lupine. Each samples was divided into two parts, one for extraction of aflatoxins and the other for isolation of aflatoxigenic fungi.

\section{Analysis of food samples for detection of aflatoxin :}

Aflatoxins were extracted from the food samples according to either AOAC method (1975) or method of Seitz and Mohr (1977). The latter method was used for extracting only from samples such as corn (zea mays) and was found to be quicker, easier and less expensive than the first method. Thin layer chromatography of aflatoxins and samples extracts were performed on silicagel DG 254. The plates were developed first with diethyl ether and then with chloroform: acetone $(9: 1 \mathrm{v} / \mathrm{v})$. Aflatoxins were identified on the basis of co-migration with aflatoxin standards (Fluka) and by their characteristic fluorescent colour under long Ultra Violet (UV) illumination at 360 nm. 
The fluorescent spots of aflatoxins were scraped off the TLC and eluted by chloroform:methanol $(9: 1 \mathrm{v} / \mathrm{v})$. The solvent was evaporated under nitrogen to dryness and the residue was dissolved in methanol. The concentration of aflatoxins (B1, B2, G1, G2 and M1) in solution was determined by measuring its absorbance at $360 \mathrm{~nm}$ then calculated according to the method of Masri, et al. (1969).

Confirmatory tests for aflatoxin :

Three different derivatives were prepared by treating portions of the isolated toxin or the aflatoxin standard with formic acid thionyl chloride, acetic acid-thionyl chloride and tri-fluoroacetic acid. The test was then continued according to the method of Stoloff (1967).

Isolation and culturing of fungi :

Attempts to isolate fungi from the food samples were made aseptically on CZapek-Dox agar plates. The plates were incubated at $28 \pm 1{ }^{\circ} \mathrm{C}$ for 3-5 days. Suspected fungal colonies were transferred to CZapek slants and incubated for one week at $28 \pm 1{ }^{\circ} \mathrm{C}$ until sporulation. Identification of the fungal isolates obtained was confirmed by the Common Wealth Mycological Institute, Kew, England. Aflatoxigenic fungi were mostly found to be of the $A$. flavus and few of them were $A$. parasiticus.

Two aflatoxin-producing liquid media were employed to investigate the potential of isolated fungi to produce aflatoxins. One media was recommended by Reddy, et al. (1971), while the other was developed by Salhab and Edwards (1978). The media were inoculated by (Ca. $10^{6}$ ) spores and incubated in a closed rotary shaker and shaked at $100-150$ r.p.m for $3-8$ days. By the end of the incubation period an equal volume of chloroform was added and the aflatoxins were extracted according to the method of Salhab and Edwards (1978).

\section{Results and Discussion}

Out of 455 food samples of 22 different types, only 5 (1.1\%) were found to contain aflatoxins. The aflatoxin contaminated samples included:peanut, rice and milk powder (table 1). The highest incidence of contamination with aflatoxin was found to occur in peanut $(7.5 \%)$ while the incidence of contamination in rice and milk powder were $(2.0 \%)$ and $(6.6 \%)$, respectively, shown in table 1 . No aflatoxins were detected in the other 19 samples. Aflatoxin B1 levels in the peanut samples varied from 98 to 1056 p.p.b., and was 28 p.p.b. in rice. Aflatoxin M1 in milk powder was 15 p.p.b. (table 2).

The data obtained through this preliminary study indicated the presence of aflatoxin in only $1.1 \%$ of the
TABLE 1. INCIDENCE OF AFLATOXINS IN SOME FOOD SAMPLES AT ALEXANDRIA PROVINCE IN EGYPT

\begin{tabular}{|c|c|c|c|}
\hline Sample Type & $\begin{array}{c}\text { Total } \\
\text { samples } \\
\text { examined }\end{array}$ & $\begin{array}{l}\text { Total samples } \\
\text { contaminated } \\
\text { with aflatoxin }\end{array}$ & $\%$ \\
\hline Peanut & 40 & 3 & 7.5 \\
\hline Rice & 50 & 1 & 2.0 \\
\hline $\begin{array}{l}\text { Wheat } \\
\text { (Triticum aestivum) }\end{array}$ & 50 & 0 & 0.0 \\
\hline $\begin{array}{l}\text { Barley } \\
\text { (Hordeum sativum) }\end{array}$ & 50 & 0 & 0.0 \\
\hline Milk powder & 15 & 1 & 6.6 \\
\hline Corn (Zea mays) & 50 & 0 & 0.0 \\
\hline $\begin{array}{l}\text { Broad beans } \\
\text { (Vicia faba) }\end{array}$ & 40 & 0 & 0.0 \\
\hline Vetch & 10 & 0 & 0.0 \\
\hline Lupine & 10 & 0 & 0.0 \\
\hline $\begin{array}{l}\text { Crushed wheat } \\
\text { (Burghol) }\end{array}$ & 10 & 0 & 0.0 \\
\hline Lentil & 15 & 0 & 0.0 \\
\hline Sesame seeds & 10 & 0 & 0.0 \\
\hline Chicken feed & 10 & 0 & 0.0 \\
\hline $\begin{array}{l}\text { Ferngreek seeds } \\
\text { (T.F.G.) }\end{array}$ & 15 & 0 & 0.0 \\
\hline $\begin{array}{l}\text { Chick peas } \\
\text { (Chicken feed) }\end{array}$ & 10 & 0 & 0.0 \\
\hline Nuts & 15 & 0 & 0.0 \\
\hline Dried figs & 10 & 0 & 0.0 \\
\hline Green pea & 15 & 0 & 0.0 \\
\hline Sesame paste & 5 & 0 & 0.0 \\
\hline Cowpea & 15 & 0 & 0.0 \\
\hline Pine nut & 5 & 0 & 0.0 \\
\hline $\begin{array}{l}\text { Liquorice } \\
\text { (Urk-us-sus) }\end{array}$ & 5 & 0 & 0.0 \\
\hline Total & 455 & 5 & 1.1 \\
\hline
\end{tabular}

TABLE 2. LEVELS OF AFLATOXIN IN CONTAMINATED FOOD SAMPLES IN EGYPT

\begin{tabular}{lcccc}
\hline $\begin{array}{l}\text { Sample } \\
\text { Type }\end{array}$ & $\begin{array}{c}\text { Total } \\
\text { sample } \\
\text { contaminated }\end{array}$ & $\begin{array}{c}\text { Country } \\
\text { of } \\
\text { origin }\end{array}$ & $\begin{array}{c}\text { Main } \\
\text { Toxin } \\
\text { found }\end{array}$ & $\begin{array}{c}\text { Levels of } \\
\text { aflatoxins } \\
\text { (p.p.b.) }\end{array}$ \\
\hline Peanut & 3 & Egypt & B1 & 934 \\
& & Egypt & B1 & 1056 \\
Rice & 1 & Egypt & B1 & 98 \\
Milk powder & 1 & Denmark & M1 & 15 \\
\hline
\end{tabular}


food samples tested. This incidence of aflatoxin contamination compared with the reported findings in other countries for similar studies is quite low. In Poland $8.7 \%$ of 150 samples examined yielded aflatoxins (Juszkiewice and Piskoka, 1977). In Egypt, aflatoxins were found in $33 \%$ of 42 samples examined (Girgis, et al., 1977) and in New Zealand, 5.3\% of 38 samples were aflatoxin contaminated (Staton, 1977). Although the incidence of aflatoxin in our foodstuffs was low the level of contamination varied from 15 to 1056 p.p.b. knowing that a level of 15 p.p.b. of aflatoxin B1 causes liver tumor in rat and rainbow trout (Lee, et al., 1971), levels reported in this study can be dangerous.

Aflatoxin incidence in peanut samples (7.5\%) table 1 compared to that reported from Thailand and the Philippines (Shank, et al., 1972; Campbell and Stoloff, 1974) is quite low.

Out of the samples studied small grains were found to be a very poor source of aflatoxins. This observation is substantiated by studies in different countries (Shank, et al., 1972; Shotwell, et al., 1975). Moreover, all bean samples were found to be aflatoxin free. This finding is in close agreement with other reported studies (Liewelly in and O' Rear, 1977; Gupta and Venkitasubramanian, 1975).

Although only $1.1 \%$ of the tested samples were found to be contaminated with aflatoxin, only $7.2 \%$ of these samples comprising 12 different foodstuffs were contaminated with aflatoxigenic fungi. Incidence of aflatoxigenic fungi in Egypt is close to the incidence rates reported from other countries, such as India (Rao, et al., 1965). Iraq (Al-Adil, et al., 1976) and Russia (L' vova, et al., 1978).

In the light of the aforementioned obtained results showed in table 3, the common types of aflatoxin produced were B1, B2 and G1 respectively. Out of 206 total isolates of aflatoxigenic fungi there are 32 toxigenic isolates with a contamination percentage of $15.5 \%$. This result agree with Reddy, et al. (1971).

The data presented in this study (table 4) showed the levels of aflatoxins produced by aflatoxigenic isolates and by Aspergillus parasiticus from different feed samples. This results are in agreement with these obtained by Wogen and Newbrene (1967).

TABLE 3. INCIDENCE OF ISOLATED AFLATOXIGENIC FUNGI

\begin{tabular}{|c|c|c|c|c|c|}
\hline Sample Type & Total sample & $\begin{array}{l}\text { Total } \\
\text { isolates }\end{array}$ & $\begin{array}{l}\text { No. of Toxigenic } \\
\text { Isolates }\end{array}$ & $\begin{array}{c}\text { Conta- } \\
\text { mination }(\%)\end{array}$ & $\begin{array}{l}\text { Aflatoxin } \\
\text { produced }\end{array}$ \\
\hline Peanut & 40 & 17 & 5 & 12.5 & $\mathrm{~B} 1, \mathrm{~B} 2$ \\
\hline Rice & 50 & 23 & 3 & 6.0 & $\mathrm{~B} 1$ \\
\hline Wheat & 50 & 21 & 3 & 6.0 & $\mathrm{~B} 1$ \\
\hline Barley & 50 & 17 & 2 & 4.0 & $\mathrm{~B} 1, \mathrm{~B} 2, \mathrm{G} 1$ \\
\hline Com & 40 & 18 & 4 & 10.0 & $\mathrm{~B} 1, \mathrm{~B} 2$ \\
\hline Broad beans & 40 & 23 & 6 & 15.0 & $\mathrm{~B} 1, \mathrm{~B} 2$ \\
\hline Lupine & 10 & 4 & 0 & 0.0 & \\
\hline Vetch & 10 & 6 & 1 & 10.0 & B1 \\
\hline Lentil & 15 & 3 & 0 & 0.0 & \\
\hline Green pea & 15 & 8 & 0 & 0.0 & \\
\hline Crushed wheat & 10 & 7 & 1 & 10.0 & $\mathrm{~B} 1$ \\
\hline Dried figs & 10 & 6 & 0 & 0.0 & \\
\hline Sesame seeds & 10 & 6 & 0 & 0.0 & \\
\hline Ground pepper & 20 & 12 & 2 & 10.0 & $\mathrm{~B} 1$ \\
\hline Spices & 10 & 7 & 0 & 0.0 & \\
\hline Chicken feed & 10 & 4 & 0 & 0.0 & \\
\hline Chick pea & 10 & 2 & 0 & 0.0 & \\
\hline Cowpea & 15 & 5 . & 1 & 6.6 & B1 \\
\hline Ferngreek seed & 15 & 7 & 2 & 13.3 & $\mathrm{~B} 2$ \\
\hline hazelnuts & 15 & 5 & 1 & 6.6 & B1 \\
\hline Pine nut & 5 & 5 & 1 & 20.0 & B1 \\
\hline Urk-us-sus & 5 & 0 & 0 & 0.0 & \\
\hline Total & 455 & 206 & 32 & 15.53 & . \\
\hline
\end{tabular}


TABLE 4. TYPE AND LEVELS OF AFLATOXINS PRODUCED BY AFLATOXIGENIC ISOLATES AND ASPERGILLUS PARASITICUS FROM SOME FOOD SAMPLES, IN EGYPT

\begin{tabular}{|c|c|c|c|}
\hline \multirow{2}{*}{ Food type } & \multirow{2}{*}{$\begin{array}{c}\begin{array}{l}\text { Aflatoxin } \\
\text { produced }\end{array} \\
\text { B1 }\end{array}$} & \multicolumn{2}{|c|}{$\begin{array}{c}\text { Levels of Aflatoxins } \\
\text { ( } \mu \mathrm{g} / 100 \mathrm{ml} \text { of media) } \\
\text { ( } \mu \mathrm{g} / \mathrm{g} \text { substrate) }\end{array}$} \\
\hline & & 622 & 76 \\
\hline & B2 & 103 & 13 \\
\hline & G1 & - ve & 6 \\
\hline & G2 & - ve & Trace \\
\hline \multirow[t]{4}{*}{ Rice } & B1 & 821 & 100 \\
\hline & B2 & - ve & 7 \\
\hline & G1 & - ve & 11 \\
\hline & G2 & - ve & Trace \\
\hline \multirow[t]{4}{*}{ Pine nut } & B1 & $-v e$ & 71 \\
\hline & $\mathrm{B} 2$ & - ve & 11 \\
\hline & G1 & - ve & 5 \\
\hline & $\mathrm{G} 2$ & - ve & Trace \\
\hline Liquorice & B1 & - ve & 0.95 \\
\hline Wheat & $\mathrm{B} 1$ & 512 & $-v e$ \\
\hline \multirow[t]{2}{*}{ Corn } & B1 & 1004 & - ve \\
\hline & B2 & 918 & $-v e$ \\
\hline Broad bean & $\mathrm{B} 1$ & 1315 & - ve \\
\hline Vetch & B1 & 918 & - ve \\
\hline \multirow[t]{3}{*}{ Barley } & B1 & 721 & - ve \\
\hline & B2 & 214 & - ve \\
\hline & G1 & 12 & - ve \\
\hline $\begin{array}{l}\text { Crushed wheat } \\
\text { (Burghol) }\end{array}$ & B1 & 115 & - ve \\
\hline Black pepper & $\mathrm{B} 1$ & 427 & - ve \\
\hline Cowpea & B1 & 1584 & - ve \\
\hline Ferngreek seeds & B2 & 215 & $-v e$ \\
\hline Hazelnut & $\mathrm{B} 1$ & 284 & $-\mathrm{ve}$ \\
\hline
\end{tabular}

From public health point of view, aflatoxin $B 1$ is the most potent hepatocarcinogenic agent so far recognized (Wogen and Newbrene, 1967). It is suspected of being a primary cause of human cancer in certain areas in Africa, South China, Hawaii, India, Rumania and elsewhere (Newbrene and Rogers, 1973). In addition, numerous reports from different laboratories appeared recently in the literature concerning a possible role of aflatoxin B1 in the etiology of Reye's syndrome (Bourgoois, et al., 1969; Oslon, et al., 1971 and Reyan, et al., 1979). It is likely that the earlier disease outbreak labelled as mouldy corn toxicosis and aspergillus toxicosis were mainly caused by aflatoxins in the feed.

For the prevention of aflatoxicosis in man, the following instructions, precautions and suggested recommended points must be taken into consideration which includes: Avoidance of contaminated feeds by monitoring batches for aflatoxin content is suggested. Young nearly weaned, pregnant and lactating animals require special protection from suspected toxic feeds. Consequently all food products which are spoilt through mould and yeast must be totally condemned. Moreover, mould and yeast must be considered as indication of food sanitary quality and hygienic status. This demands more strict hygienic measures on foodstuffs to minimize the risk of aflatoxins on the consumers.

\section{Literature Cited}

Al-Adil, M. K., A. B. Abdul Nour, A. S. Yahia and A. K. Daod. 1976. Contamination by Aspergillus flavus group of some foodstuffs in Baghdad area. Technical Bulletin No. 5, 530-536.

Adamson, R. H., P. Correa and D. W. Dalgard. 1973. BRIEF COMMUNICATION : Occurrence of primary liver carcinoma in rehesus monkey fed aflatoxin B. J. Nath. Cancer Inst. 50:549-553.

Association of Official Analytical Chemists. 1975. Natural Poisons. In William Horwitz (Editor). Official Methods of Analysis, Chapter 26, 265-274.

Bourgoois, C. H., N. Keshchamras and D. S. Comer. 1969. Under encephalopathy: Fatal cerebral oedema and fatty degeneration of the viscera in Thai children. J. Med. Assoc. Thai, 52:4552-4556.

Borut, V. S. and A. Z. Joffe. 1965. Aspergillus flavus link Aflatoxin and toxicity of groundnut in Palestine, Israel. J. Bot. 198-203.

Butler, W. H. and J. M. Barnes. 1968. Carcinogenic action of groundnut meal containing aflatoxin inrats. Food Cosmet. Toxicol. 6:135-141.

Campbell, T. C. and L. Stoloff. 1974. Implication of mycotoxin for human health. J. Agr. Food Chem. 22:1006-1015.

Ciegler, A. 1977. Fungi that produce mycotoxins: CONDITION AND OCCURRENCE. Paper presented at the 2 nd International Mycological Congress. Tampa, Florida, August, 27-September 3.

Girgis, A. N., S. El-Sherif, N. Fofael and S. Nesheim. 1977. Aflatoxins in Egyptian Foodstuffs. J. Assoc. of Anal. Chem. 60:746-747.

Gopalan, C., P. G. Tulpule and D. Krishnamurthy. 1972. 
Induction of hepatic carcinoma with aflatoxin in the hesus monkey, Food Cosment. Toxicol. 10:519-521.

Gupta, S. K. and T. A. Venkitasubramanian. 1975. Production of aflatoxin on Soyabeans. Appl. Microbiol. 29:834-836.

Juszkiewica, T. and Piskoka-Pliszcsynska. 1977. Occurrence of mycotoxins in mixed feeds and concentrates. J. Med. Water 33:193-196.

-Lee, D. J., J. H. Wales and R. O. Sinnhuber. 1971. Promotion $\mathrm{C}$ of aflatoxin-induced hepatoma gorwth in trout by methyl melonate and sterculate. Cancer Res. 31:960-963.

Liewellyn, G. C. and C. E. O'rear. 1977. Examination of fungal growth and aflatoxin production on marihuena. Mycopathologin. 62:109-112.

L'vova, L. S., A. P. Shulgina, T. I. Shatilova and C. I. Kizlenko. 1978. Biosynthesis of mycotoxins by fungi of the Genera Aspergillus and Penicillium isolated from grains. Prikladmayaa Biokhimiyali Microbiologiya, 14:735-742.

Masri, M. S., J. R. Paye and V. C. Garcia. 1969. Analysis for aflatoxin $M$ in milk. J. Ass. Office, Anal, Chem. 51:594-600.

Newbrene, P. M. and A. E. Rogers. 1973. Animal model of human disease : Primary of hepatocellular carcinoma. Am. J. Pathol. 72:137-246.

Olson, L. C., C. H. Bourgeois and R. S. Cotton. 1971. Encephalopathy and fatty degeneration of the viscera in North Eastern Thailand, Clinical Syndrome and Epidemiology. Pediatrics 47:707-709.

Rao, K. W., T. V. Madthuran and P. G. Tupule. 1965. Incidence of toxigenic strains of Asperqillus flavus of feeding groundnut crop in certain coast district of India. Indian Med. Res. 53:1196-1202.
Reddy, T. V., L. Viswanathan and T. A. Venkitasubramanian. 1971. High aflatoxin production of a chemically defined medium. Appl. Microbiol. 22:393-396.

Reyan, N. J., R. K. Hogan, W. Hayes, P. Unger and M. Siraj. 1979. Aflatoxin B1: It's role in the etiology of Reye's Syndrome. Pediatrics, 64:71-74.

Salhab, A. S. and G. S. Edwards. 1978. Biosynthetic production of $\left(\mathrm{C}^{14}\right)$ aflatoxin. J. of Labelled Compounds and Radiopharmaceutical, 15:41 46.

Seitz, L. M. and H. W. Mohr. 1977. New method for quantitation of aflatoxin in corn. Cerela Chem. 54: 179-183.

Shank, R. C., J. E. Gordon, C. N. Wogan, A. Nondosuta and B. Subhamari. 1972. Dietry aflatoxins and human liver cancer, I. Field survey of rural Thai families for ingested aflatoxins. Food Cosmet. Toxico. 10:71-84.

Shotwell, O. L., C. W. Hasseltine, R. D. Stubblefield and W. G. Sorenson. 1966. Production of aflatoxin on rice. Appl. Microbiology, 14:425-428.

Shotwell, O. L., M. L. Goulden, D. I. Funnel and C. W. Hesseltine. 1975. Survey of wheat for aflatoxin and ochratoxin. Cereal Chem. 55:373-380.

Staton, D. W. 1977. A survey of some foods for aflatoxins. Food Technol. Anal. 12:25-32.

Stoloff, L. 1967. Collaborative study of a method for identification of aflatoxin B1 by derivative formation. J. Assoc. Office. Anal. Chemists. 50:354-360.

Stoloff, L. 1976. Incidence, distribution and disposition of products containing aflatoxins. Proceeding of the American Phytopathological Society. 3:156-178.

Wogen, G. N. and P. M. Newbrene. 1967. Dose response characteristic of aflatoxin B1 carcinogenesis in the rat. Cancer Res. 27:2370-2376. 
$\ldots$ 